\title{
Photosynthetic Light Response and Epidermal Characteristics of Sun and Shade Pecan Leaves
}

\author{
Leonardo Lombardini ${ }^{1,5}$, Hermann Restrepo-Diaz ${ }^{2,4}$, and Astrid Volder ${ }^{3}$ \\ Texas A\&M University, Department of Horticultural Sciences, College Station, TX 77843-2133
}

\begin{abstract}
AdDitional Index words. Carya illinoinensis, photosynthetic photon flux, stomatal density
Abstract. An experiment was conducted to investigate the morphologic characteristics and photosynthetic response of sun and shade leaves of mature pecan [Carya illinoinensis (Wangenh.) K. Koch] trees. Treatments were established according to leaf type (sun or shade leaves) and cultivar (Pawnee and Stuart). Sun leaves were chosen from those growing on exterior portions of the tree canopy and exposed to full sunlight for most of the day $\left[\geq 1500 \mu \mathrm{mol} \cdot \mathrm{m}^{-2} \cdot \mathrm{s}^{-1}\right.$ photosynthetic photon flux $(P P F)]$. Shade leaves were those growing in interior parts of the tree canopy $(\leq 100$ $\left.\mu \mathrm{mol} \cdot \mathrm{m}^{-2} \cdot \mathrm{s}^{-1} \mathrm{PPF}\right)$. Epidermis characteristics, leaf area, and chlorophyll (Chl) content were also measured. Results indicated that stomatal density (stomata $/ \mathrm{mm}^{2}$ ), leaf area, and leaflet area were greater in sun leaves than in shade leaves in both cultivars investigated. Specific leaf area was greater in shade leaves than sun leaves. Chlorophyll fluorescence, total $\mathrm{Chl}$ content, $\mathrm{Chl}$ a, $\mathrm{Chl}$ b, and $\mathrm{Chl}$ a/b were unaffected by leaf type or cultivar. In both cultivars, photosynthetic light response curves showed that area-based maximum assimilation rate $\left(A_{\text {max }}\right)$ in shade leaves was about half of that measured in sun leaves in June through August. However, in October, $A_{\max }$ of sun leaves dropped to values similar to those measured in shade leaves. Light compensation point of photosynthesis and dark respiration rate were always lower in shade leaves than in sun leaves. Overall, there were only minor differences between the cultivars. Pecan trees require careful canopy management to avoid self shading and to maintain productivity. These results could help determine optimal levels of canopy light interception and could be used to develop canopy and crop management practices.
\end{abstract}

Pecan is the most valuable nut tree native to North America (Hall, 2000). Its native range extends from northern Illinois and southeastern Iowa to the Gulf Coast of the United States where it grows abundantly along the Mississippi River, the rivers of central and eastern Oklahoma, and the Edwards Plateau in Texas (Thompson and Grauke, 1991). Isolated populations are also found in Mexico, where it grows as far south as the state of Oaxaca (Thompson and Grauke, 1991). Today, pecan is cultivated outside its native range, and commercial production has been expanded to many other regions of the United States and Mexico.

The tree canopy is a complex solar collection system possessing leaf and shoot subsystems consisting of numerous parts. Orchard crops, such as pecan, typically intercept $65 \%$ to $70 \%$ of the available sunlight (Wood, 1996) with up to $95 \%$ light interception in overcrowded, unpruned orchards (Lombardini, 2006). Orchard profitability depends on efficient absorption and use of light because sunlight is the source of energy that drives the biological production of dry mass (Garriz et al., 1998). Therefore, many training and pruning techniques are designed to maximize total light interception as well as to ensure good light penetration into the canopy ( $\mathrm{Li}$ and Lakso, 2004). Low irradiance affects net photosynthesis $\left(\mathrm{P}_{\mathrm{N}}\right)$ directly by reducing the utilization of photon energy, but this effect

\footnotetext{
Received for publication 12 Feb. 2009. Accepted for publication 26 May 2009. Mention of a trademark, proprietary product, or vendor does not constitute a guarantee or warranty of the product by the authors, the Texas A\&M University, Texas AgriLife, or sponsors of the research, and does not imply its approval to the exclusion of other products or vendors that also may be suitable.

${ }^{1}$ Associate Professor.

${ }^{2}$ Visiting Scientist.

${ }^{3}$ Assistant Professor.

${ }^{4}$ Current address: Faculty of Agronomy, National University of Colombia, Bogotá, Colombia.

${ }^{5}$ Corresponding author. E-mail: 1-lombardini@tamu.edu.
}

differs between plants and is dependent on their saturation irradiance (Gregoriou et al., 2007). Thus, the relationship between $\mathrm{P}_{\mathrm{N}}$ and $P P F$ density provides information that is useful as a physiological model of leaf, plant, or canopy growth (Hanson et al., 1987).

Morphological, physiological, and biochemical modifications are required for acclimation of photosynthesis to high and low light levels (Björkman, 1981; Taiz and Zeiger, 2006). Leaves on the outside of the tree canopy are typically adapted to high light (sun leaves), while leaves growing in the more shaded, inner canopy generally exhibit adaptations to low light conditions (shade leaves) (Lambers and Poorter, 1992). Sun and shade leaves have additional contrasting characteristics. Sun leaves are able to increase light-saturated photosynthetic capacity by increasing soluble protein, rubisco activity, and components of the electron-transport chain (Olsen et al., 2002). Shade leaves have inherently low photosynthetic rates, contain more total chlorophyll per reaction center, have a smaller $\mathrm{Chl} \mathrm{a} / \mathrm{b}$ ratio, and are generally thinner than sun leaves (Björkman, 1981; Taiz and Zeiger, 2006).

Carbon assimilation is not the only component of plant gas exchange affected by solar radiation intensity. Species limited in natural distribution to moist sunny locations have dark respiration rate $\left(\mathrm{R}_{\mathrm{d}}\right)$ values in the range of 0.67 to $1.33 \mu \mathrm{mol} \cdot \mathrm{m}^{-2} \cdot \mathrm{s}^{-1}$ of $\mathrm{CO}_{2}$, whereas $\mathrm{R}_{\mathrm{d}}$ in species from the shaded floor of dense forests range from 0.10 to $0.27 \mu \mathrm{mol} \cdot \mathrm{m}^{-2} \cdot \mathrm{s}^{-1}$ of $\mathrm{CO}_{2}$ (Björkman, 1968). Light compensation point $\left(\mathrm{L}_{\mathrm{CP}}\right)$ is the level of illumination at which photosynthetic fixation of carbon dioxide matches respiratory loss. Reported $\mathrm{L}_{\mathrm{CP}}$ values for various fruit trees species range between 1 and $25 \mu \mathrm{mol} \cdot \mathrm{m}^{-2} \cdot \mathrm{s}^{-1}$ for shade leaves and between 28 and $67 \mu \mathrm{mol} \cdot \mathrm{m}^{-2} \cdot \mathrm{s}^{-1}$ for sun leaves (Vanden Heuvel et al., 2004). In sun leaves of nut trees, reported $\mathrm{L}_{\mathrm{CP}}$ values are $29 \mu \mathrm{mol} \cdot \mathrm{m}^{-2} \cdot \mathrm{s}^{-1}$ (Rosati et al., 2006) and $56 \mu \mathrm{mol} \cdot \mathrm{m}^{-2} \cdot \mathrm{s}^{-1}$ 
(Higgins et al., 1992) for almond [Prunus dulcis (Mill.) D.A. Webb] and $52 \mu \mathrm{mol} \cdot \mathrm{m}^{-2} \cdot \mathrm{s}^{-1}$ for hazelnut (Corylus avellana L.) (Hampson et al., 1996).

Several authors have studied the effect of light availability in orchard crops. Shading reduced total leaf area in walnut (Juglans regia L.) (Atanasova et al., 2003; Ryugo et al., 1980), altered leaf chlorophyll concentration and $\mathrm{Chl} \mathrm{a} / \mathrm{b}$ ratio in grapefruit (Citrus paradisi Macf.) and sweet orange (Citrus sinensis L.) (Syvertsen and Smith, 1984), hazelnut (Hampson et al., 1996), and peach [Prunus persica (L.) Batsch.] (Kappel and Flore, 1983), decreased the stomatal density in hazelnut (Hampson et al., 1996) and olive (Olea europaea L.) (Gregoriou et al., 2007), and reduced $\mathrm{R}_{\mathrm{d}}$, maximum net $\mathrm{CO}_{2}$ assimilation $\left(\mathrm{A}_{\max }\right)$, lowered $\mathrm{L}_{\mathrm{CP}}$ in grapevine (Vitis vinifera $\mathrm{L}$.) (Vanden Heuvel et al., 2004), and affected light-saturated photosynthesis in apple (Malus ×domestica Borkh.) (Li and Lakso, 2004). When pecan trees were shaded for $14 \mathrm{~d}$ with shadecloth $(30 \%$ full sunlight), $\mathrm{P}_{\mathrm{N}}$ and transpiration rate were reduced compared with leaves in full sunlight by $60 \%$ to $70 \%$ and $50 \%$, respectively (Andersen and Brodbeck, 1995). The same study also showed that short-term shading induced physiological adaptations such as reduced $\mathrm{R}_{\mathrm{d}}, \mathrm{L}_{\mathrm{CP}}$ and light saturation point.

Pruning is a common practice in orchard management for the improvement of light penetration and utilization and for increasing flowering and fruiting. Hedge-pruning increased the amount of light penetration between pecan trees, but not within individual tree canopies, and was not associated with any change in production and nut quality (Malstrom et al., 1982). A more recent study showed that some pruning techniques induced a proportional increase in the fraction of total solar radiation intercepted by the tree canopies, and that crowding reduced the amount of light intercepted per unit of leaf area (Lombardini, 2006).

While the short-term effect of artificially shaded leaves of young pecan trees has been investigated early in the growing season (Andersen and Brodbeck, 1995), there is no information about the photosynthetic performance of sun and shade leaves of mature pecan trees. In particular, little is known about the change in photosynthesis activity of pecan leaves throughout the growing season. The objective of the present work was to quantify the effects of differences in light intensity on the morphological characteristics and seasonal physiological performance of sun and shade leaves of field-grown pecan trees. The two cultivars chosen (Pawnee and Stuart) differ in their history and utilization and are probably the two most important ones used commercially (Grauke and Thompson, 1995; Thompson and Grauke, 1991; Thompson and Grauke, 2000; Thompson and Hunter, 1985). 'Stuart' has been the most popular cultivar for almost a century (Grauke and Thompson, 1995), while 'Pawnee' has recently become the most widely planted pecan cultivar (Thompson and Grauke, 2000). Both cultivars have a moderate tendency to biennial bearing, but there are few published results on their seasonal carbon assimilation and the effect of additional light received at the leaf level.

\section{Materials and Methods}

The experiment was conducted during the 2007 growing season at the Texas A\&M University J. Benton Storey Pecan Experimental Orchard (lat. $30^{\circ} 31^{\prime} \mathrm{N}$, long. $96^{\circ} 24^{\prime} \mathrm{W}$, elevation $67 \mathrm{~m}$ ), located near College Station. The 3.5-ha orchard was established in 1984 on a Westwood silt loam soil $(0 \%$ to $1 \%$ slope, fine-silty, mixed, thermic Fluventic Ustochrepts). Five mature pecan trees per cultivar (Pawnee and Stuart) were randomly selected based on uniformity of size, vigor, crop load (selected trees had $10 \%$ to $20 \%$ of terminals with fruit), and location within the orchard. All trees were spaced at $10.7 \times 10.7 \mathrm{~m}$ and had $56 \pm 5 \mathrm{~cm}$ diameter trunks measured at $1.3 \mathrm{~m}$ above the ground. Pecan trees were managed according to the recommendations of Texas AgriLife Extension for commercial pecan management, which included rowcover crop maintenance, weed removal, nutrient management, and pesticide application (Texas Agricultural Extension Service, 2007). 'Pawnee' trees were harvested on 27 Sept., and 'Stuart' trees were harvested on 22 Oct.

Treatments were established according to the leaf type (sun or shade leaves). Sun leaves were growing on exterior portions of the tree canopy and were exposed to full sunlight $(\geq 1500$ $\mu \mathrm{mol} \cdot \mathrm{m}^{-2} \cdot \mathrm{s}^{-1} P P F$ ) for most of the day (southern exposure). Shade leaves were growing in interior parts of the tree canopy $\left(\leq 100 \mu \mathrm{mol} \cdot \mathrm{m}^{-2} \cdot \mathrm{s}^{-1} \mathrm{PPF}\right)$. Above- and inside-canopy $P P F$ was measured using a ceptometer (AccuPAR; Decagon Scientific, Pullman, WA). Measurements were always carried out on days characterized by sunny conditions.

Photosynthetic Light Response CuRves. Light response curves were performed on three leaves per leaf type and cultivar using a portable IR gas analyzer (LI-6400; LI-COR, Lincoln, $\mathrm{NE}$ ) equipped with a standard LI-6400, $2 \times 3-\mathrm{cm}$ leaf chamber and a red/blue light source (6400-02B, LI-COR). Four sets of 3-d measurements [26-28 June, 30 July-1 Aug., 28-30 Aug., and 17-19 Oct. (referred to as "June," "July," "August," and "October" measurements, respectively)] were carried out in the orchard between 1000 and $1500 \mathrm{HR}$. At each measurement set, one curve per leaf type per tree per day was created, for a total of 60 curves per set. At the time of measurement, leaf temperature ranged between 25 and $30{ }^{\circ} \mathrm{C}$ and chamber temperature was kept constant at $30{ }^{\circ} \mathrm{C}$. Chamber $\mathrm{CO}_{2}$ concentration was kept constant at $380 \mu \mathrm{L} \cdot \mathrm{L}^{-1}$ and light levels were obtained using the red/blue light source connected to the IR gas analyzer, which was programmed to provide nine $P P F$ levels $(0,50,200,400,600,800,1000,1200$, and 1500 $\left.\mu \mathrm{mol} \cdot \mathrm{m}^{-2} \cdot \mathrm{s}^{-1}\right)$. Measurements were performed on vegetative branches (about $2 \mathrm{~cm}$ in stem diameter) that were cut from the midportion of the canopy using a pole pruner and were immediately placed in water, where the stems were recut to reduce the risk of embolism in the xylem. Leaves were allowed to adapt to each light level for 2 min before each point was recorded. $A_{\max }, R_{d}$, and $L_{C P}$ were calculated by fitting data to the nonlinear regression model described by Hanson et al. (1987), with PPF levels as the independent variable.

Chlorophyll analysis. After completion of the August set of light response curves, 20 to $30 \mathrm{mg}$ of leaf lamina was collected using a paper puncher from the same leaflet used for the curve, avoiding major veins. Leaf portions were placed in $80 \%$ acetone, and $\mathrm{Chl}$ extraction was completed using the method described by Kirk (1968). The amount of absorbance was read at 645 and $663 \mathrm{~nm}$ using a spectrophotometer (model UV1700; Shimadzu, Columbia, MD). Absorbance readings were used to calculate leaf Chl concentrations (Kirk, 1968). Leaf absorbance readings were also taken during the August measurements using a chlorophyll meter (SPAD-502; Minolta, Ramsey, NJ) as a nondestructive tool for estimating leaf Chl (Markwell et al., 1995).

Chlorophyll Fluorescence. Leaf chlorophyll fluorescence measurements were carried out during the August measurements 
using a continuous excitation chlorophyll fluorescence analyzer (Handy PEA; Hansatech Instruments, Kings Lynn, UK). Leaves were acclimated to the dark using lightweight leaf clips for at least $20 \mathrm{~min}$ before measurements were taken (Greer, 1995). Baseline $\left(\mathrm{F}_{0}\right)$ and maximum $\left(\mathrm{F}_{\mathrm{m}}\right)$ fluorescence were measured and variable $\left(\mathrm{F}_{\mathrm{v}}=\mathrm{F}_{\mathrm{m}}-\mathrm{F}_{0}\right)$ fluorescence and the ratio of variable fluorescence to maximum fluorescence $\left(\mathrm{F}_{\mathrm{v}} / \mathrm{F}_{\mathrm{m}}\right)$ ratio were calculated from these data.

Epidermis CHARACTERISTiCs. Fifteen fruit and leaf type per tree were collected during the July set of measurements to determine stomatal density [SD (measured in number of stomates per square millimeter)] and trichome density [TD (measured in number of trichomes per square millimeter)]. Leaves and fruit were collected from branches adjacent to those used for the photosynthetic light response curves. SD and TD in leaves and fruit were estimated following the technique described by Sagaram et al. (2007). Trichome type on the fruit epidermis was determined according to the description done by Grauke et al. (1987).

LEAF AREA. One compound leaf per treatment was collected during the July and August measurements, scanned with a compact color flatbed scanner (PowerLook 2100XL; UMAX, Taipei, Taiwan), and saved as a digital image (TIFF format). Leaf area was then measured from the digital images using a Java image-processing program (Image J; National Institute of Mental Health, Bethesda, MD). Leaf fresh and dry mass (FM and DM, respectively) of the same leaves were measured gravimetrically, and specific leaf area (SLA) was calculated on a dry mass basis by dividing the leaf area of one leaf by its dry mass. Dry mass-based photosynthesis $\left[\mathrm{A}_{\operatorname{mass}}\left(\mathrm{nmol} \cdot \mathrm{g}^{-1} \cdot \mathrm{s}^{-1}\right)\right]$ was calculated as $\mathrm{A}_{\text {area }}\left(\mu \mathrm{mol} \cdot \mathrm{m}^{-2} \cdot \mathrm{s}^{-1}\right) \times \operatorname{SLA}\left(\mathrm{m}^{2} \cdot \mathrm{kg}^{-1}\right)$.

STATISTICAL ANALYSIS. Data were subjected to analysis of variance by using a completely randomized design. Where a significant $F$-test was observed, means separation between treatments was obtained using Tukey's test. Data were analyzed using Statistix (version 8.0; Analytical Software, Tallahassee, FL). Individual photosynthetic response curves were fitted using nonlinear regression through the average of three measurements per tree at each light level (Sigmaplot 9.0; Systat Software, San Jose, CA) using the equation provided by Hanson et al. (1987).

\section{Results}

Photosynthetic Light Response Curves. Photosynthetic light response curves did not reveal clear differences between 'Pawnee' (Fig. 1) and 'Stuart' (Fig. 2). In both cultivars, net $\mathrm{CO}_{2}$ assimilation rate was greater in sun leaves than in shade leaves. On each date, shade leaves had lower $A_{\max }, L_{C P}$, and $R_{d}$ than sun leaves (Fig. 3). Compared with the measurements in June, 95\% $\mathrm{A}_{\max }$ was reached at higher light intensities (hereafter referred to as the light saturation point) at subsequent
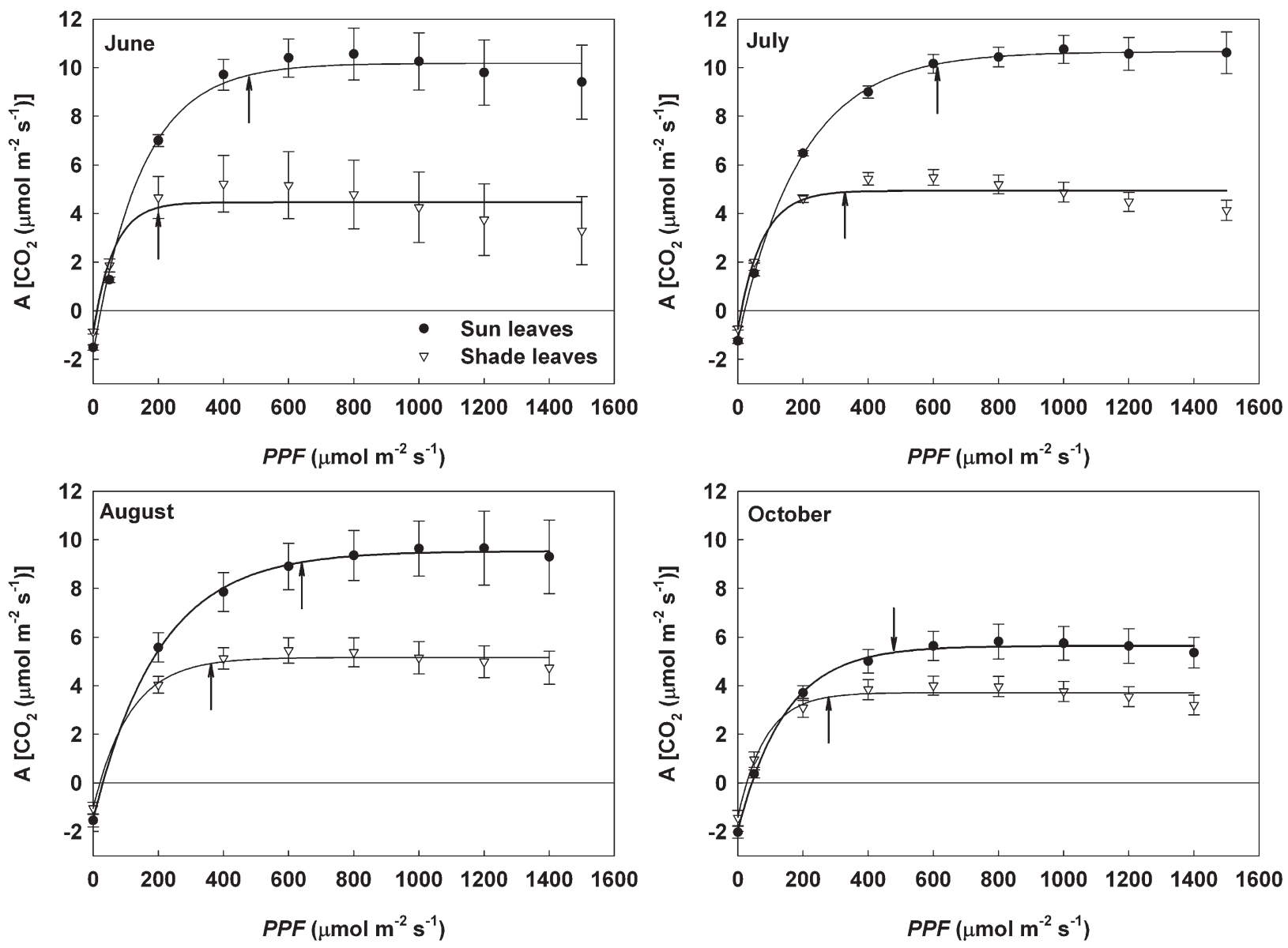

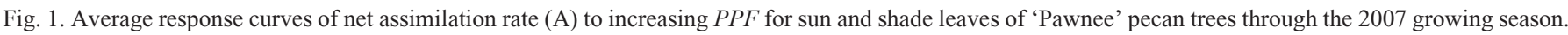
Data are average \pm SE $(n=5)$; curves were fitted according to Hanson et al. (1987). Arrows indicate $95 \%$ of maximum light saturated photosynthesis $\left(A_{\text {max }}\right)$. 

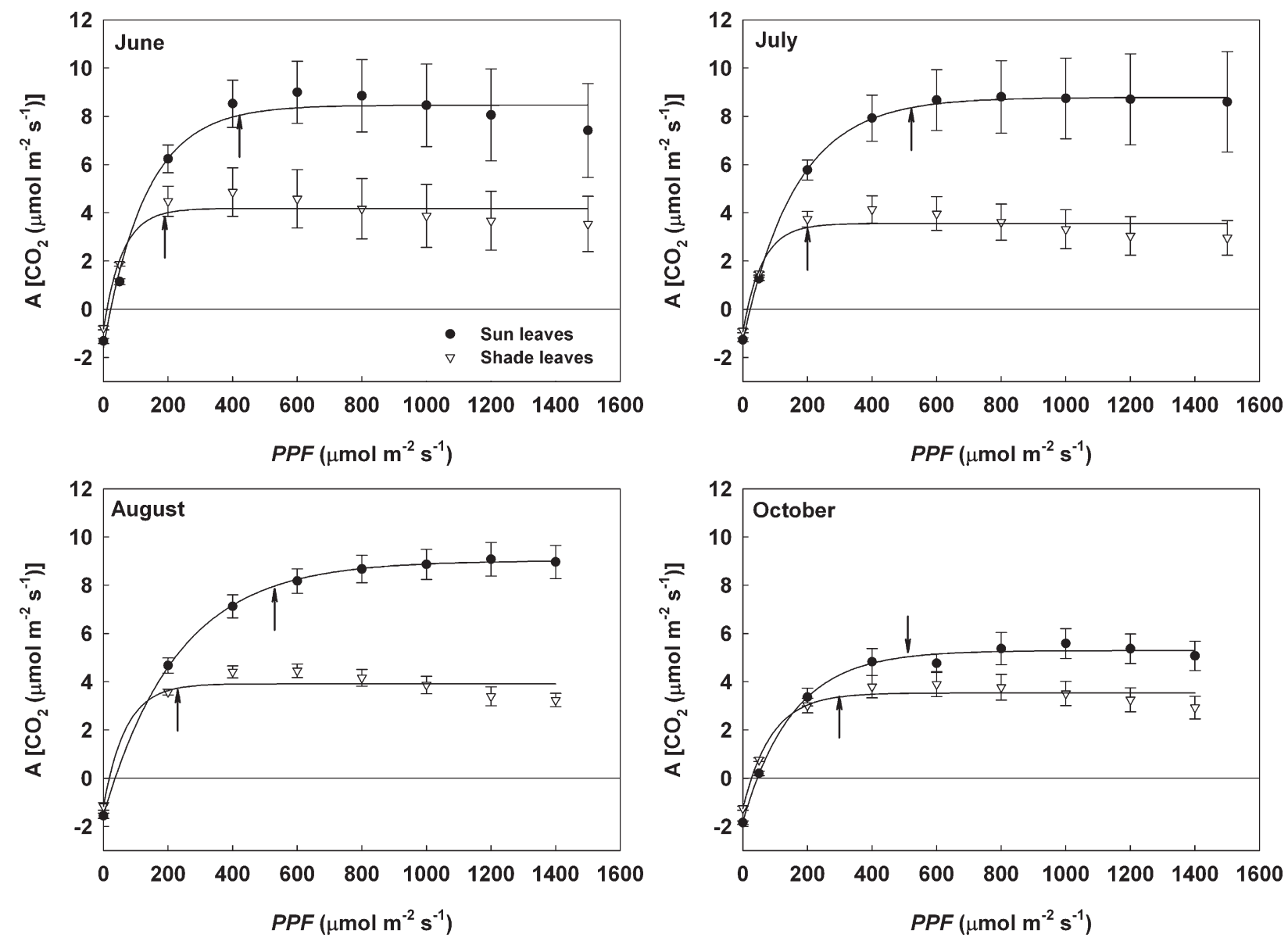

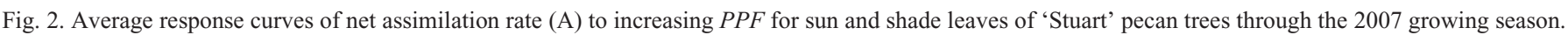
Data are average $\pm \operatorname{SE}(n=5)$; curves were fitted according to Hanson et al. (1987). Arrows indicate $95 \%$ of maximum light saturated photosynthesis $\left(A_{\text {max }}\right)$.

dates (Figs. 1 and 2). For both cultivars, this lead to reduced quantum use efficiency for leaves growing later in the season. Quantum use efficiency values (assimilated $\mathrm{CO}_{2}$ /quanta received) at the light saturation point decreased from 0.020 in June, to 0.017 in July, to 0.014 in August, and $0.011 \mu \mathrm{mol} \cdot \mu_{\mathrm{mol}}^{-1}$ in October for 'Pawnee' sun leaves, and from 0.021 in June, to 0.020 in July, to 0.014 in August, and $0.007 \mu \mathrm{mol} \cdot \mu \mathrm{mol}^{-1}$ in October for 'Pawnee' shade leaves. For 'Stuart', these values decreased from 0.019 in June to 0.016 for sun leaves growing in July and August to $0.010 \mu \mathrm{mol} \cdot \mathrm{Hmol}^{-1}$ in September. Quantum use efficiency of shade leaves of 'Stuart' decreased from 0.021 in June to 0.017 in July to 0.016 in August and $0.011 \mu \mathrm{mol} \cdot \mu_{\mathrm{mol}}{ }^{-1}$ in September. Values of $\mathrm{A}_{\max }$ remained relatively stable in shade leaves during all sampling dates. In sun leaves, $A_{\max }$ varied little on the first three sampling dates but showed a $60 \%$ reduction on the fourth measurement (Fig. 3, $\mathrm{A}$ and $\mathrm{B}$ ), whereas this reduction was not observed in shade leaves. In general, $\mathrm{R}_{\mathrm{d}}$ (Fig. 3, C and D) remained constant throughout the season in shade leaves of both cultivars, but decreased in sun leaves. $\mathrm{L}_{\mathrm{CP}}$ increased through time (Fig. 3, E and $F$ ) for leaves of both cultivars and this trend was observed in sun and shade leaves, although at different intensities. In 'Pawnee', $\mathrm{L}_{\mathrm{CP}}$ was identical in sun and shade leaves on the last measurement of the season.

Chlorophyll analysis. 'Stuart' leaves had 10\% more total Chl per unit fresh weight than 'Pawnee' leaves $(P=0.067$, Table 1). This was almost entirely due to the higher Chl b content in 'Stuart' leaves $(+13 \%, P=0.026$, Table 1$)$ compared with 'Pawnee' leaves. This is also supported by the higher Chl $\mathrm{a} / \mathrm{b}$ ratio in 'Pawnee' leaves (2.1 vs. $2.0, P=0.053$, Table 1$)$. There was no statistically significant effect of leaf type on the total Chl concentration, in spite of a small increase in Chl b concentration in the shade leaves of both cultivars $(+11 \%, P=$ 0.064 , Table 1). SPAD readings indicated that 'Stuart' sun leaves had a higher leaf absorbance than the other leaf types. $\mathrm{F}_{\mathrm{v}} / \mathrm{F}_{\mathrm{m}}$ was higher in 'Pawnee' sun leaves than in shade leaves ( 0.82 vs. $0.78, P<0.05$, Table 1$)$, but was unaffected by leaf type in 'Stuart.' There was also a cultivar $\times$ leaf type interaction, with a greater decrease in Fv/Fm ratio in 'Pawnee' leaves due to the shade ( 0.82 vs. 0.78$)$ than in 'Stuart' leaves $(0.81$ vs. 0.80$)$.

LEAF AREA. For both cultivars, SLA was greater for shade leaves (Table 2). $A_{\text {mass }}$ did not differ between the cultivars, and was only significantly higher for 'Pawnee' sun leaves when compared with 'Stuart' shade leaves (Table 2).

EPIDERmis Characteristics. Leaf SD was affected by cultivar and leaf type (Table 3). 'Stuart' had 42\% and 34\% greater SD than 'Pawnee' for sun and shade leaves, respectively. Within the same cultivar, SD of sun leaves was $23 \%$ and $30 \%$ greater than shade leaves in 'Pawnee' and 'Stuart', respectively. There was no cultivar $\times$ leaf position interaction. SD in fruit was between $1 \%$ and $2 \%$ of leaf SD and, as for leaf $\mathrm{SD}$, fruit exposed to the sun had a greater SD than those growing in the shade. Density of either trichome type was unaffected by leaf type or cultivar (Table 3 ). Density of concave 


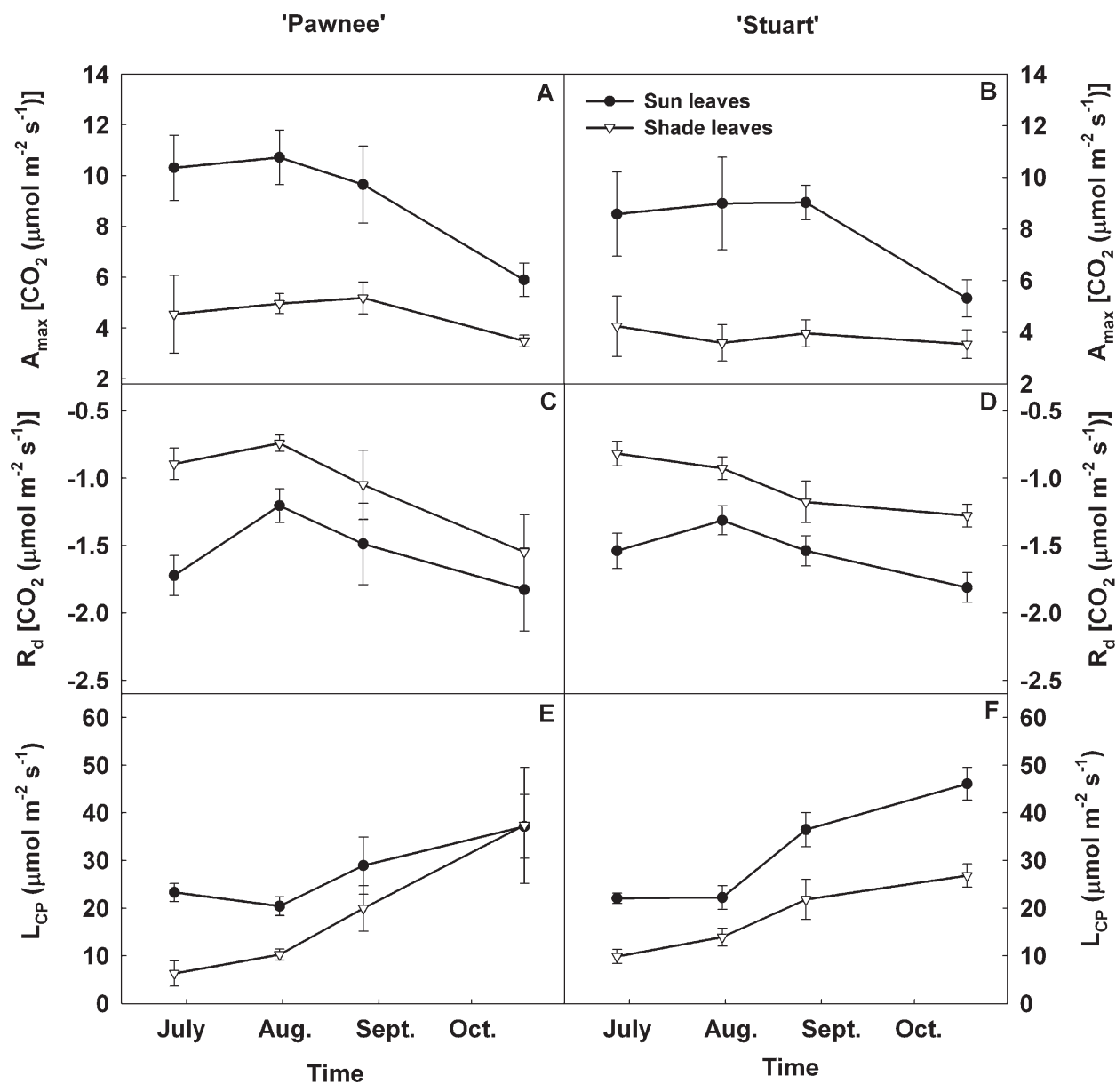

Fig. 3. Maximum photosynthetic rate $\left(A_{\max }\right)(\mathbf{A}$ and $\mathbf{B})$, dark respiration rate $\left(\mathrm{R}_{\mathrm{d}}\right)(\mathbf{C}$ and $\mathbf{D})$, and light compensation point $\left(\mathrm{L}_{\mathrm{CP}}\right)(\mathbf{E}$ and $\mathbf{F})$ for sun and shade leaves of 'Pawnee' $(\mathbf{A}, \mathbf{C}, \mathbf{E})$ and 'Stuart' $(\mathbf{B}, \mathbf{D}$, and $\mathbf{F})$ pecan trees through the 2007 growing season. Data were calculated from curves fitted for individual trees $(n=5)$ with the method of Hanson et al. (1987). Bars indicate \pm SE.

peltate trichomes was the same in both cultivars and fruit type. The number of bladder-like trichomes in 'Pawnee' sun fruit was about three times greater than in 'Stuart' shade fruit.

\section{Discussion}

The study revealed that pecan shade leaves exposed to saturating radiation are about half as effective as sun leaves in assimilating $\mathrm{CO}_{2}$. Light saturation points were lower for shade leaves and steadily increased as the season progressed for both leaf types. In both leaf types and cultivars, quantum use efficiency values were similar at a specific measurement date, but decreased as the growing season progressed. The research also revealed that late-season photosynthetic capacity was maintained in shade leaves, whereas it was reduced to about $60 \%$ in sun leaves. There were no major physiological or morphological differences between 'Pawnee' and 'Stuart', although the two cultivars differ greatly in their history, origin, and phenology. 'Pawnee' originated in 1963 from a controlled cross of 'Mohawk' and 'Starking Hardy Giant' done at the U.S. Department of Agriculture, Agricultural Research Service station in Brownwood, TX (Thompson and Hunter, 1985); it is protandrous (i.e., male flowers develop first) and is very early in nut maturation, with fruit maturing in mid-September in central Texas (Thompson and Grauke, 2000). 'Stuart' originated from a seedling planted around 1874 from a nut of unknown parentage in Pascagoula, MS. 'Stuart' is protogynous (i.e., female flowers develop first) and ripens in midseason (i.e., late October/early November in central Texas) (Thompson and Grauke, 2000). The only differences between the two cultivars were observed in some of the parameters related to the photosynthetic apparatus $(\mathrm{Chl}$ and $\mathrm{Fv} / \mathrm{Fm})$ (Table 1) and in the magnitude of SD (Table 3). Sun and shade leaves of 'Stuart' had, in fact, a greater SD than sun and shade leaves of 'Pawnee'. Because 'Stuart' leaves had greater SD than 'Pawnee', it could be expected that gas exchange and leaf biomass accumulation are accordingly greater. However, the greater SD observed in 'Stuart' did not lead to greater $\mathrm{A}_{\max }$, SLA, or $\mathrm{A}_{\text {mass }}$ (Table 2, Fig. 3). This suggests that the overall stomatal conductance $\left(g_{\mathrm{S}}\right)$ was smaller in 'Stuart' or that the photosynthetic process in 'Pawnee' is somehow more efficient than in 'Stuart'. Because $g_{\mathrm{S}}$ has a proportionally greater effect on water vapor exchange than $\mathrm{CO}_{2}$ exchange during times of moderate to low water availability (Jarvis and McNaughton, 1986), we could also expect that 'Stuart' leaves may be more water efficient, but this hypothesis remains to be tested. The very low SD found in the fruit epidermis is in the range reported for most species (Aschan

Table 1. Chlorophyll (Chl) content, SPAD reading, and Fv/Fm ratio of sun and shade leaves of 'Pawnee' and 'Stuart' pecan trees.

\begin{tabular}{llcccccc}
\hline Cultivar & Leaf type & $\begin{array}{c}\text { Chl a } \\
\left(\mathrm{mg}^{-1} \mathrm{FM}\right)\end{array}$ & $\begin{array}{c}\text { Chl b} \\
\left(\mathrm{mg} \cdot \mathrm{g}^{-1} \mathrm{FM}\right)\end{array}$ & $\begin{array}{c}\text { Total Chl } \\
\left(\mathrm{mg}^{-1} \mathrm{FM}\right)\end{array}$ & Chl a/Chl b & SPAD & Fv/Fm \\
\hline \multirow{2}{*}{ Pawnee } & Sun & $2.3 \mathrm{a}^{\mathrm{z}}$ & $1.1 \mathrm{~b}$ & $3.4 \mathrm{~b}$ & $2.1 \mathrm{a}$ & $47.8 \mathrm{~b}$ \\
\multirow{3}{*}{ Stuart } & Shade & $2.5 \mathrm{a}$ & $1.2 \mathrm{ab}$ & $3.7 \mathrm{ab}$ & $2.1 \mathrm{a}$ & $46.4 \mathrm{~b}$ \\
& Sun & $2.5 \mathrm{a}$ & $1.2 \mathrm{a}$ & $3.7 \mathrm{ab}$ & $2.0 \mathrm{a}$ & $50.2 \mathrm{a}$ & $0.81 \mathrm{~b}$ \\
& Shade & $2.7 \mathrm{a}$ & $1.4 \mathrm{a}$ & $4.0 \mathrm{a}$ & $2.0 \mathrm{a}$ & $46.4 \mathrm{~b}$ & $0.80 \mathrm{ab}$
\end{tabular}

${ }^{\mathrm{z}}$ Means within column separated using Tukey's test. Means followed by the same letter are not significantly different at $P<0.05$. 
Table 2. Specific leaf area (SLA) and dry mass-based photosynthesis $\left(\mathrm{A}_{\text {mass }}\right)$ of sun and shade leaves of 'Pawnee' and 'Stuart' pecan trees.

\begin{tabular}{lccc}
\hline Cultivar & Leaf type & $\begin{array}{c}\text { SLA }^{\mathrm{z}} \\
\left(\mathrm{m}^{2} \cdot \mathrm{kg}^{-1} \mathrm{DM}\right)\end{array}$ & $\begin{array}{c}\mathrm{A}_{\text {mass }} \\
\left(\mathrm{nmol} \cdot \mathrm{g}^{-1} \cdot \mathrm{s}^{-1}\right)\end{array}$ \\
\hline Pawnee & Sun & $10.6 \pm 0.4 \mathrm{~b}^{\mathrm{y}}$ & $114.5 \pm 13.7 \mathrm{a}$ \\
& Shade & $15.3 \pm 0.3 \mathrm{a}$ & $75.6 \pm 5.9 \mathrm{ab}$ \\
Stuart & Sun & $11.9 \pm 0.6 \mathrm{~b}$ & $103.8 \pm 16.5 \mathrm{ab}$ \\
& Shade & $16.5 \pm 0.4 \mathrm{a}$ & $58.7 \pm 10.7 \mathrm{~b}$ \\
\hline
\end{tabular}

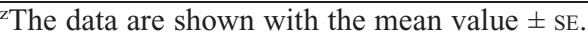

${ }^{y}$ Means within column separated using Tukey's test. Means followed by the same letter are not significantly different at $P<0.05$.

and Pfanz, 2003). One of the reasons for the low SD in fruit is that the number of stomates is set at anthesis and therefore their density decreases with fruit expansion (Blanke and Lenz, 1989). The low fruit SD indicates that despite the presence of apparent chlorophyll (not measured), pecan fruit likely have very low gas exchange rates with the atmosphere. Carbon assimilation in reproductive organs is quite common in herbaceous and annual plants (Aschan and Pfanz, 2003). The small $\mathrm{SD}$ found in fruit epidermis does not necessarily translate into low photosynthetic rates. While leaves and green stems are specialized in light harvesting and photosynthetic assimilation by using atmospheric $\mathrm{CO}_{2}$, chlorophyll-containing bark, fruit, and root typically perform photosynthesis by recycling $\mathrm{CO}_{2}$ produced by respiratory processes (Aschan and Pfanz, 2003).

While no clear differences were revealed by chlorophyll analysis, SPAD measurements, or chlorophyll fluorescence between sun and shade leaves of either cultivar, distinct differences were found in epidermal and physiological features. As expected, shade leaves in both cultivars had greater SLA (Table 2), lower $A_{\text {mass }}$ (Table 2), and lower SD (Table 3). As reported for other shade leaves or plants (Björkman, 1981), $R_{d}$ and $\mathrm{L}_{\mathrm{CP}}$ were lower in shade leaves than in sun leaves. Only in October were $R_{d}$ and $L_{C P}$ similar in the two leaf types of 'Pawnee'. When compared at the same date, 'Pawnee' shade leaves had reduced $\mathrm{R}_{\mathrm{d}}$ and greater $\mathrm{L}_{\mathrm{CP}}$, compared with 'Stuart' shade leaves, suggesting a loss of efficiency, possibly due to more advanced senescence in 'Pawnee'. This could be related to the early nut maturation of 'Pawnee' and to the fact that 'Pawnee' trees had been harvested for about 3 weeks at the time of the October measurements while 'Stuart' trees were still bearing nuts.

Crews et al. (1980) found a statistically significant decrease in activity of rubisco between May and August in three pecan cultivars (Brooks, Mobile, and Stuart), without differences among the cultivars. The same study also reported a $40 \%$ decrease in net photosynthetic rate between 15 Aug. and 15
Sept. Sparks and Brack (1972) reported that the presence of leaves in 'Stuart' late in the growing season was crucial in affecting return bloom and fruit set the following year. When leaves were removed on 1 Sept., the number of pistillate flowers/shoot and the numbers of fruit set/shoot decreased, thus indicating that even if carbon assimilation rate in late season is lower, it is still crucial for fruit development (Sparks and Brack, 1972).

Interestingly, both cultivars showed a similar decline in $\mathrm{A}_{\max }$ at the time of the October measurement. Although in 'Pawnee', the decline could have been caused by the removal of the fruiting sink strength caused by early harvest, the similar reduction observed in 'Stuart' (which had not been harvested at the time of the October measurement) suggests that leaf senescence rather than modification of the source/sink ratio was the likely cause of the reduced photosynthetic performance. Wood (1988) found that the presence of fruit in the "on" alternate-bearing phase increased photosynthesis and inhibited the rate of leaf senescence in pecan trees. However, the study compared trees in the "on" versus "off" year and not preversus postharvest conditions, as was the case for the results presented here.

Sun leaves had higher rates of $\mathrm{A}_{\max }$ than shade leaves and maintained this advantage for most of the growing season. The literature indicates that shade leaves are more efficient under low light conditions thanks to a specialized anatomy (e.g., singlelayered palisade parenchyma and a higher SLA) and physiological adaptations (e.g., reduced Chl a/b) (Givnish, 1988; Taiz and Zeiger, 2006). Results from this study show an increased SLA in shade leaves of both cultivars; however, we did not observe a shift in $\mathrm{Chl} \mathrm{a} / \mathrm{b}$ ratio.

The results presented here may explain why pecan trees in general can tolerate severe hedging-type pruning and still maintain high productivity in areas characterized by relatively high light regions such as the southwestern United States and east-central Australia. The reduction of canopy size caused by hedging likely increases the ratio of sun-exposed leaves to shaded leaves, thus boosting carbon gain per unit leaf area. Recent research has proved that hedging programs are not recommended for more humid regions such as the southeastern United States because of the overall lower seasonal solar radiation, which may prohibit sun leaves from performing photosynthesis at full capacity (Wood, 2009).

The results from this study present new information on photoassimilation characteristics of pecan foliage. Although there were no major differences in the photosynthetic performance of the two cultivars chosen, it could still be worthwhile to compare these results with other cultivars and study the importance of seasonal carbon assimilation, particularly late in the season. The autumn assimilation drop in sun leaves, without

Table 3. Epidermis characteristics of sun and shade leaves and fruit of 'Pawnee' and 'Stuart' pecan trees.

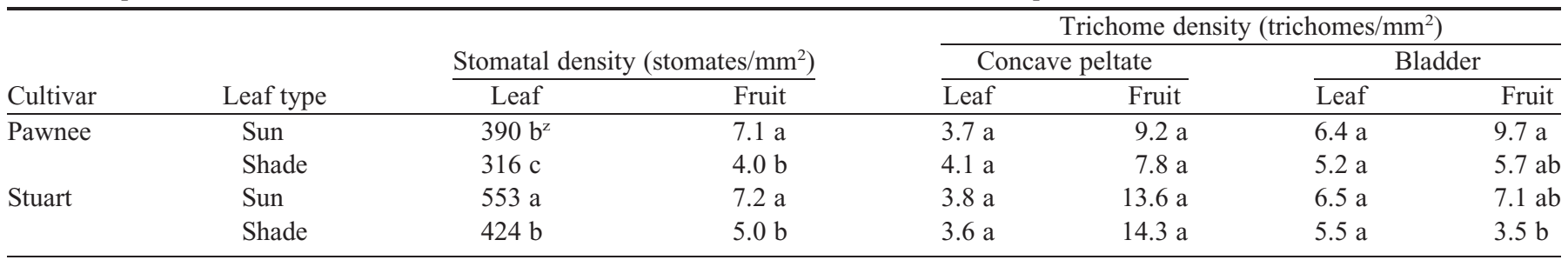

${ }^{\mathrm{z}}$ Means within column separated using Tukey's test. Means followed by the same letter are not significantly different at $P<0.05$. 
a corresponding assimilation drop in shade leaves, is especially noteworthy and is a significant finding. The results provide baseline information relevant to improving management of alternate bearing and development of improved canopy pruning strategies (i.e., management of the orchard light environment). Carbon assimilation studies may offer additional insights to help understand the role of early nut maturation and late-season carbon assimilation in relation to alternate bearing. Investigations such as the one presented here may eventually help to identify pecan cultivars capable of maintaining high photosynthetic rates at lower light levels.

\section{Literature Cited}

Andersen, P.C. and B.V. Brodbeck. 1995. Light preconditions and fluctuating irradiance levels influence gas exchange of pecan leaves, p. 148-159. In: M.W. Smith, W. Reid, and B.W. Wood (eds.). Sustaining pecan productivity into the 21st century: 2nd Natl. Pecan Wkshp. Proc. U.S. Dept. Agr., Agr. Res. Serv. 1995-3.

Aschan, G. and H. Pfanz. 2003. Non-foliar photosynthesis: A strategy of additional carbon acquisition. Flora 198:81-97.

Atanasova, L., D. Stefanov, I. Yordanov, K. Kornova, and L. Kavardzikov. 2003. Comparative characteristics of growth and photosynthesis of sun and shade leaves from normal and pendulum walnut (Juglans regia L.) trees. Photosynthetica 41:289292.

Björkman, O. 1968. Carboxydismutase activity in shade-adapted and sun-adapted species of higher plants. Physiol. Plant. 21:1-10.

Björkman, O. 1981. Responses to different quantum flux densities, p. 57-107. In: O.L. Lange, P.S. Nobel, C.B. Osmond, and H. Zeigler (eds.). Encyclopedia of plant physiology, New Series. Springer, Berlin.

Blanke, M.M. and F. Lenz. 1989. Fruit photosynthesis. Plant Cell Environ. 12:31-46.

Crews, C.E., R.E. Worley, J.P. Syvertsen, and M.G. Bausher. 1980. Carboxylase activity and seasonal changes in $\mathrm{CO}_{2}$ assimilation rates in three cultivars of pecan. J. Amer. Soc. Hort. Sci. 105:798801.

Garriz, P.I., G.M. Colavita, and H.L. Alvarez. 1998. Fruit and spur leaf growth and quality as influenced by low irradiance levels in pear. Scientia Hort. 77:195-205.

Givnish, T.J. 1988. Adaptation to sun and shade: A whole-plant perspective. Aust. J. Plant Physiol. 15:63-92.

Grauke, L.J. and T.E. Thompson. 1995. Pecan cultivars. 12 June 2009. $<\mathrm{http}$ //extension-horticulture.tamu.edu/carya/pecans/cvintro.htm $>$.

Grauke, L.J., J.B. Storey, and E.R. Emino. 1987. Influence of leaf age on the upper and lower leaf surface features of juvenile and adult pecan leaves. J. Amer. Soc. Hort. Sci. 112:835-841.

Greer, D.H. 1995. Effect of canopy position on the susceptibility of kiwifruit (Actinidia deliciosa) leaves on vines in an orchard environment to photoinhibition throughout the growing season. Aust. J. Plant Physiol. 22:299-309.

Gregoriou, K., K. Pontikis, and S. Vemmos. 2007. Effects of reduced irradiance on leaf morphology, photosynthetic capacity, and fruit yield in olive. Photosynthetica 45:172-181.

Hall, G.D. 2000. Pecan food potential in prehistoric North America. Econ. Bot. 54:103-112.

Hampson, C.R., A.N. Azarenko, and J.R. Potter. 1996. Photosynthetic rate, flowering, and yield component alteration in hazelnut in response to different light environments. J. Amer. Soc. Hort. Sci. 121:1103-1111.

Hanson, P.J., R.E. McRoberts, J.G. Isebrands, and R.K. Dixon. 1987. An optimal sampling strategy for determining $\mathrm{CO}_{2}$ exchange rate as a function of photosynthetic photon flux density. Photosynthetica 21:98-101.

Higgins, S.S., F.E. Larsen, R.B. Bendel, G.K. Radamaker, J.H. Bassman, W.R. Bidlake, and A.A. Wir. 1992. Comparative gas exchange characteristics of potted, glasshouse-grown almond, apple, fig, grape, olive, peach and asian pear. Scientia Hort. 52:313-329.

Jarvis, P.G. and K.G. McNaughton. 1986. Stomatal control of transpiration: Scaling up from leaf to region. Adv. Ecol. Res 15:149.

Kappel, F. and J.A. Flore. 1983. Effect of shade on photosynthesis, specific leaf weight, leaf chlorophyll content, and morphology of young peach trees. J. Amer. Soc. Hort. Sci. 108:541-544.

Kirk, J.T.O. 1968. Studies on the dependence of chlorophyll synthesis on protein synthesis in Euglena gracilis, together with a nomogram for determination of chlorophyll concentration. Planta 78: 200-207.

Lambers, H. and H. Poorter. 1992. Inherent variation in growth rate between higher plants: A search for physiological causes and ecological consequences. Adv. Ecol. Res 23:187-261.

Li, K.T. and A.N. Lakso. 2004. Photosynthetic characteristics of apple spur leaves after summer pruning to improve exposure to light. HortScience 39:969-972.

Lombardini, L. 2006. One-time pruning of pecan trees induced limited and short-term benefits in canopy light penetration, yield and nut quality. HortScience 41:1469-1473.

Malstrom, H.L., T.D. Riley, and J.R. Jones. 1982. Continuous hedge pruning affects light penetration, and nut production of 'Western' pecan trees. Pecan Qrtly. 16:4-15.

Markwell, J., J. Osterman, and J. Mitchell. 1995. Calibration of the Minolta SPAD-502 leaf chlorophyll meter. Photosynth. Res. 46:467472.

Olsen, R.T., J.M. Ruter, and M.W. Rieger. 2002. Photosynthetic responses of container-grown Illicium L. taxa to sun and shade. J. Amer. Soc. Hort. Sci. 127:919-924.

Rosati, A., S.G. Metcalf, R.P. Buchner, A.E. Fulton, and B.D. Lampinen. 2006. Physiological effects of kaolin applications in well-irrigated and water-stressed walnut and almond trees. Ann. Bot. (Lond.) 98: 267-275.

Ryugo, K., B. Marangoni, and D.E. Ramos. 1980. Light intensity and fruiting effects on carbohydrate contents, spur development, and return bloom of 'Hartley' walnut. J. Amer. Soc. Hort. Sci. 105:223227.

Sagaram, M., L. Lombardini, and L.J. Grauke. 2007. Variation in leaf anatomy of pecan cultivars from three ecogeographic locations. J. Amer. Soc. Hort. Sci. 132:592-596.

Sparks, D. and C.E. Brack. 1972. Return bloom and fruit set of pecan from leaf and fruit removal. HortScience 7:131-132.

Syvertsen, J.P. and M.L. Smith. 1984. Light acclimation in citrus leaves. I. Changes in physical characteristics, chlorophyll, and nitrogen content. J. Amer. Soc. Hort. Sci. 109:807-812.

Taiz, L. and E. Zeiger. 2006. Plant physiology. Sinauer Associates, Inc., Sunderland, MA.

Texas Agricultural Extension Service. 2007. Texas pecan handbook. Texas A\&M Univ. System, College Station.

Thompson, T.E. and L.J. Grauke. 1991. Pecans and other hickories (Carya). Acta Hort. 290:839-904.

Thompson, T.E. and L.J. Grauke. 2000. 'Pawnee' pecan. J. Amer. Pomol. Soc. 54:110-113.

Thompson, T.E. and R.E. Hunter. 1985. 'Pawnee' pecan. HortScience 20:776.

Vanden Heuvel, J.E., J.T.A. Proctor, K.H. Fisher, and J.A. Sullivan. 2004. Shading affects morphology, dry-matter partitioning, and photosynthetic response of greenhouse-grown 'Chardonnay' grapevines. HortScience 39:65-70.

Wood, B.W. 1988. Fruiting affects photosynthesis and senescence of pecan leaves. J. Amer. Soc. Hort. Sci. 113:432-436.

Wood, B.W. 1996. Canopy morphology of pecan cultivars. HortScience 31:139-142.

Wood, B.W. 2009. Mechanical hedge pruning of pecan in a relatively low-light environment. HortScience 44:68-72. 